\title{
Study of Blood Urea, Serum Creatinine and Serum Electrolytes in Azotemic Patients Undergoing Dialysis
}

\author{
Zahida Nasreen ${ }^{1}$, Mohammed Siddique Ahmed Khan ${ }^{2}$, Abdul Qadir ${ }^{3}$, Maanasa ${ }^{4}$ \\ 1,2,4 Department of Biochemistry, Shadan Institute of Medical Sciences, Teaching Hospital \& Research Centre, Hyderabad. Telangana, \\ India. 500027 \\ ${ }^{3}$ Gulf Medical College, Gulf Medical University, Ajman, UAE (United Arab Emirates)
}

\begin{abstract}
To study the blood urea, serum creatinine, serum electrolytes in normal healthy subjects and comparing the results with azotemic patients undergoing dialysis so as to prevent advancing kidney diseases and to reduce morbidity and mortality. Objectives: Awareness of the abnormalities in the azotemic patients that can arise under various conditions and in order to prevent adverse outcomes by doing dialysis.
\end{abstract}

Keywords: CKD

\section{Introduction}

The elderly population has been growing rapidly over the past few decades. This rise is due to advancement in medical care $^{(1,2)}$. This growth parallels the incidence of chronic kidney disease which is associated with diabetes and hypertension ${ }^{3}$. They are over more than 20 million persons with chronic kidney disease (CKD) stage 1-5 of which 8 millions have CKD stage 3-5 which are associated with various metabolic and electrolyte abnormalities that results from the decline in kidney function. These changes are expected to occur with advancing disease, unexpected blood urea, serum creatinine and electrolytes abnormalities may occur.

Therefore it is important to be aware of the potential abnormalities that can arise under various conditions and in order to prevent adverse outcomes, dialysis of chronic kidney disease (CKD) patients is important to decrease morbidity and mortality.

\section{Materials and Methods}

- Inclusion criteria : no. of patients : 20 patients (age range) of ckd undergoing dialysis selected for this study as cases 20 healthy subjects as controls (age) .

- Sample collection: Sample collection before dialysis, sample amount, collected in plain tubes. $10 \mathrm{ml}$ of blood samples are collected from cases and controls, $5 \mathrm{ml}$ of blood centrifuged for estimation of serum creatinine and electrolytes. Whereas from $5 \mathrm{ml}$ of whole blood is used for the estimation of blood urea.

- Study centre: Shadan Institute of Medical Sciences, Teaching Hospital and Research Centre

- Exclusion criteria: Subjects suffering from liver diseases excluded in this study

\section{Estimation of Serum electrolytes}

The electrolytes, Sodium, Potassium and chloride in serum were measured using Flame photometry method ( Make:) following the instructions provided along with the kit.

\section{Estimation of Urea and Creatinine}

Blood Urea and Serum Creatinine were estimated using the standard kit by Berthelot, End Point Assay and Jaffe's method respectively. Data are expressed as mean \pm standard deviation (SD). The significant difference between the test group and the control group were analyzed using Anova. Data were analyzed using the SPSS software. A value of $\mathrm{p}<0.05$ was set as the level of significance.

\section{Results}

The mean age of patients in the control and test groups was $41.9 \pm 14$ and $49.20 \pm 12$ years respectively. The blood urea in the study group $(136.9 \pm 36 \mathrm{mg} / \mathrm{dl})$ was significantly higher $(\mathrm{p}<0.001)$ as compared to the control group $(24.5 \pm 4.8$ $\mathrm{mg} / \mathrm{dl}$ ). Similar results were obtained while evaluating serum creatinine. The levels were significantly higher in study group $(9.29 \pm 2.9 \mathrm{mg} / \mathrm{dl})$ in contrast to the control group where the serum creatinine levels were $0.94 \pm 0.1 \mathrm{mg} / \mathrm{dl}$.

The assessment of serum electrolytes was carried out in both the groups. The levels of sodium in serum of the patients in the study group $(137.45+7.3)$ showed a slight decrease as compared to the control group $(139.6+3.1)$ which was considered non significant $(p>0.05)$. However the level of serum potassium varied in both the groups. There was significant difference in potassium levels $(\mathrm{p}<0.05)$ in control $(3.9+0.2--)$ and study group $(5.1+0.7)$. Serum chloride did not show much difference $\mid(p>0.05)$. The level of serum chloride in control group was $102.2+2.4$ whereas in the study group it was $103.6+5.8$. 
International Journal of Science and Research (IJSR)

ISSN (Online): 2319-7064

Index Copernicus Value (2013): 6.14 | Impact Factor (2014): 5.611

\begin{tabular}{|l|l|l|}
\hline \multicolumn{3}{|c|}{ Distribution Age in years } \\
\hline Statistical Measures & Control Group & Study Group \\
\hline Mean & 41.90 & 49.20 \\
\hline Variance & 212.832 & 158.168 \\
\hline Std. Deviation & 14.589 & 12.577 \\
\hline Minimum & 16 & 27 \\
\hline Maximum & 70 & 74 \\
\hline Std. Error & 3.262 & 2.812 \\
\hline
\end{tabular}

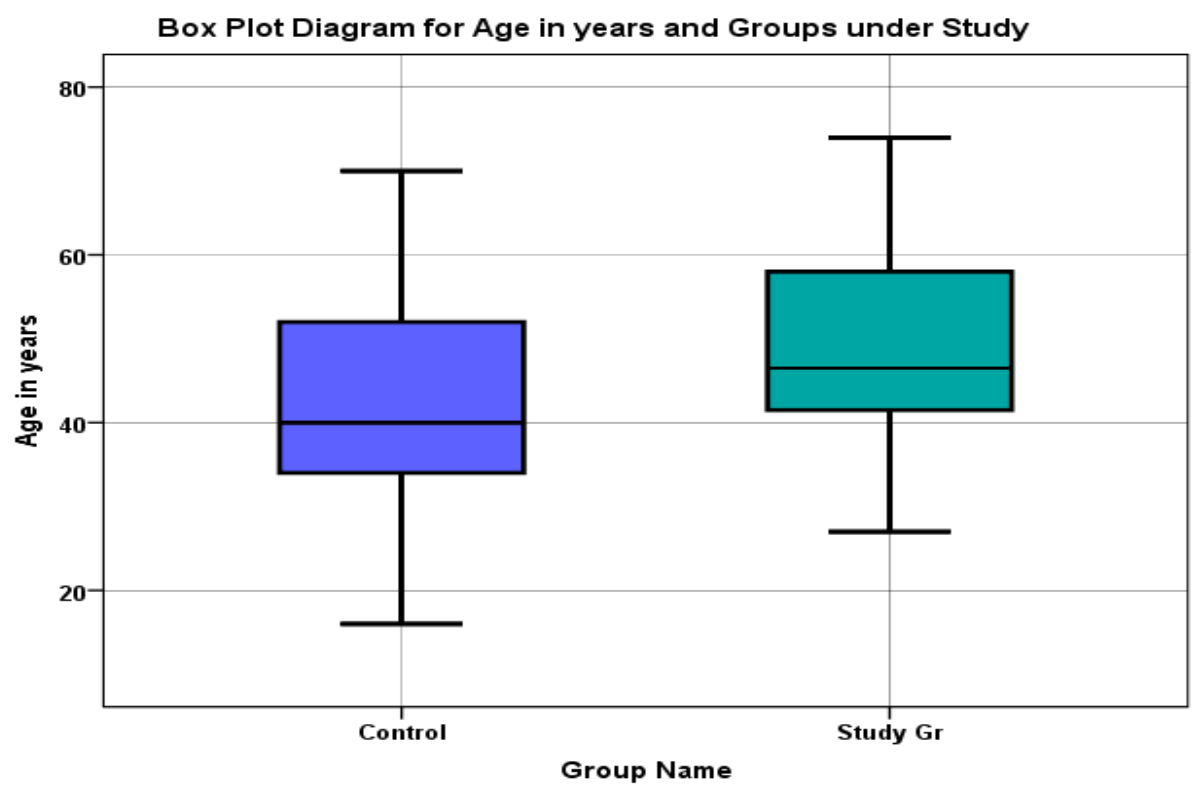

\begin{tabular}{|c|c|c|}
\hline \multicolumn{3}{|c|}{ Distribution Blood Urea } \\
\hline Statistical Measures & Control Group & Study Group \\
\hline Mean & 24.55 & 136.95 \\
\hline Variance & 23.734 & 1340.261 \\
\hline Std. Deviation & 4.872 & 36.610 \\
\hline Minimum & 14 & 72 \\
\hline Maximum & 31 & 190 \\
\hline Std. Error & 1.089 & 8.186 \\
\hline
\end{tabular}

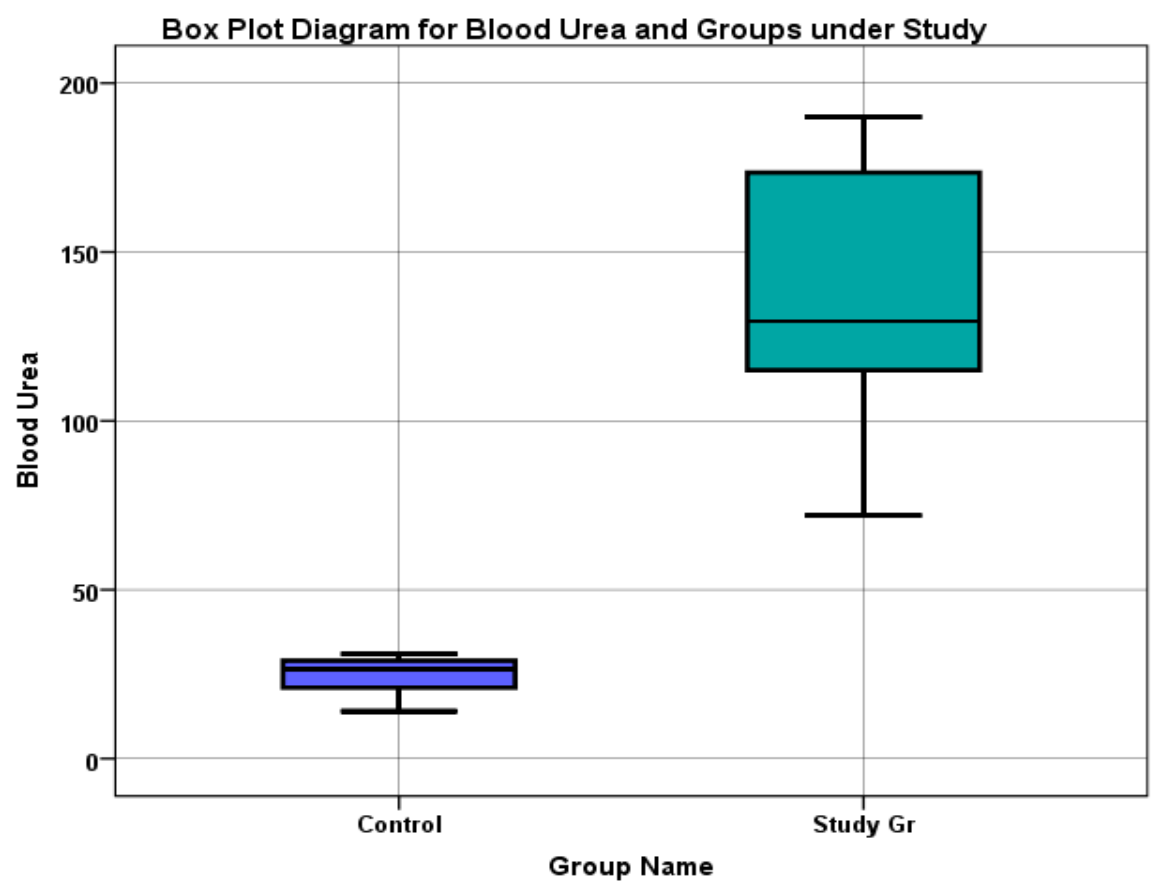

Volume 4 Issue 11, November 2015 www.ijsr.net 
International Journal of Science and Research (IJSR)

ISSN (Online): 2319-7064

Index Copernicus Value (2013): 6.14 | Impact Factor (2014): 5.611

\begin{tabular}{|c|c|c|}
\hline \multicolumn{3}{|c|}{ Distribution Serum Creatinine } \\
\hline Statistical Measures & Control Group & Study Group \\
\hline Mean & .94 & 9.29 \\
\hline Variance & .009 & 8.888 \\
\hline Std. Deviation & .093 & 2.981 \\
\hline Minimum & 1 & 5 \\
\hline Maximum & 1 & 15 \\
\hline Std. Error & 0.21 & 0.667 \\
\hline
\end{tabular}

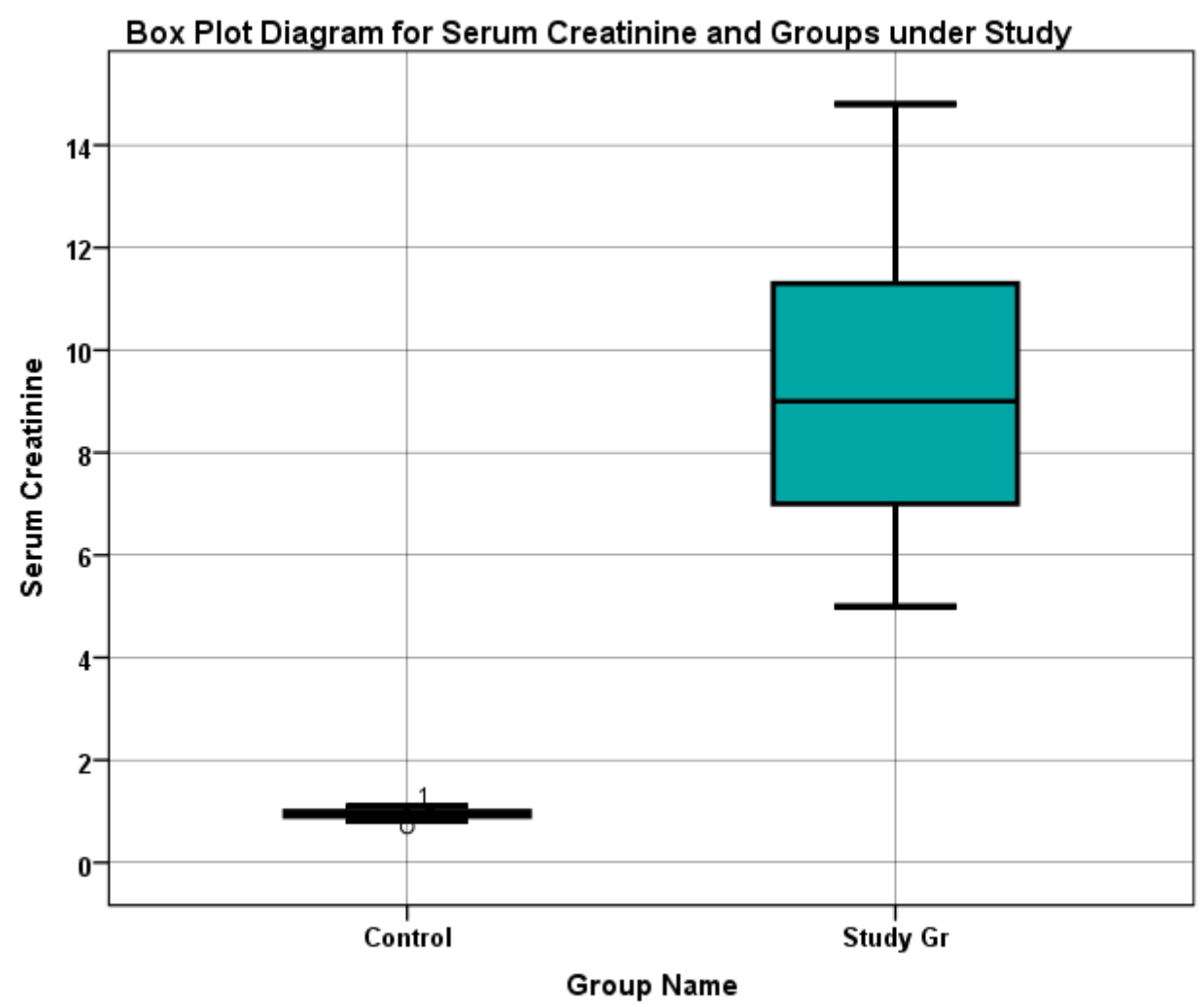

Distribution Serum Sodium

\begin{tabular}{|c|c|c|}
\hline Statistical Measures & Control Group & Study Group \\
\hline Mean & 139.65 & 137.45 \\
\hline Variance & 9.924 & 53.524 \\
\hline Std. Deviation & 3.150 & 7.316 \\
\hline Minimum & 136 & 123 \\
\hline Maximum & 147 & 149 \\
\hline Std. Error & 0.704 & 1.636 \\
\hline
\end{tabular}

Volume 4 Issue 11, November 2015

www.ijsr.net 
International Journal of Science and Research (IJSR)

ISSN (Online): 2319-7064

Index Copernicus Value (2013): 6.14 | Impact Factor (2014): 5.611

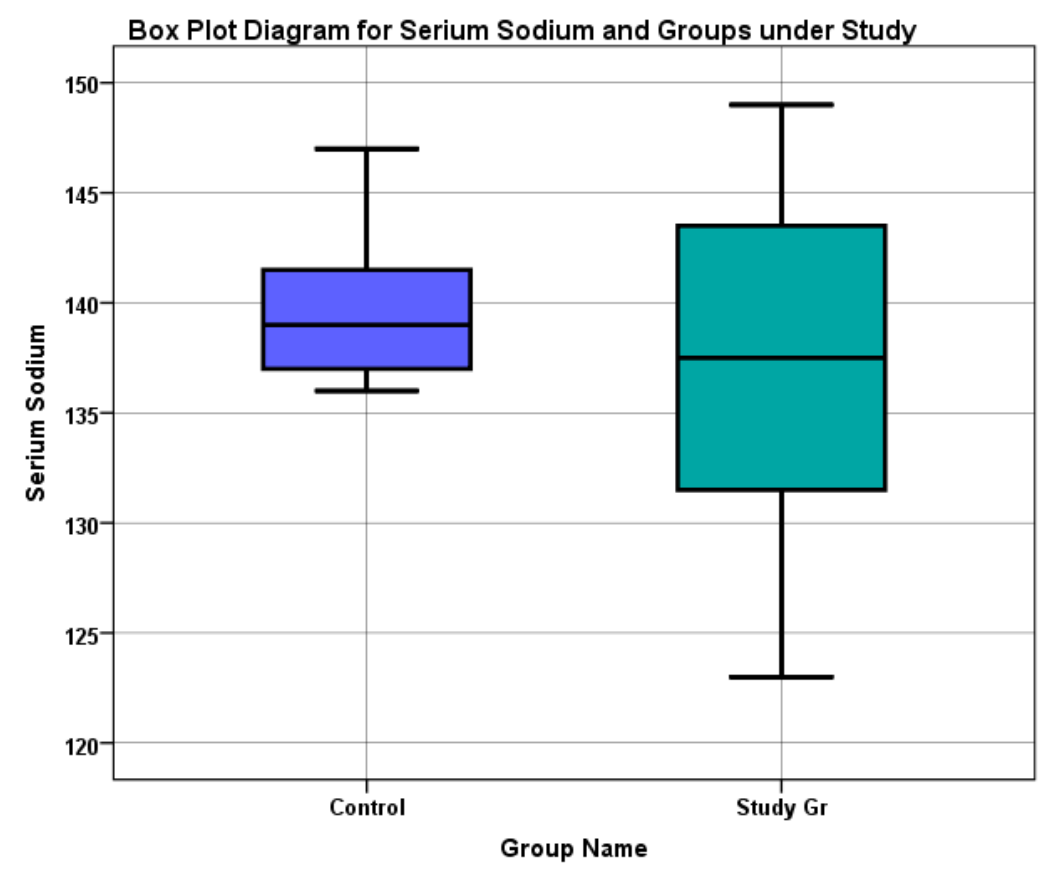

\begin{tabular}{|c|c|c|}
\hline \multicolumn{3}{|c|}{ Distribution Serum Potasium } \\
\hline Statistical Measures & Control Group & Study Group \\
\hline Mean & 3.99 & 5.09 \\
\hline Variance & .081 & .622 \\
\hline Std. Deviation & .285 & .789 \\
\hline Minimum & 4 & 4 \\
\hline Maximum & 5 & 6 \\
\hline Std. Error & 0.064 & 0.176 \\
\hline
\end{tabular}

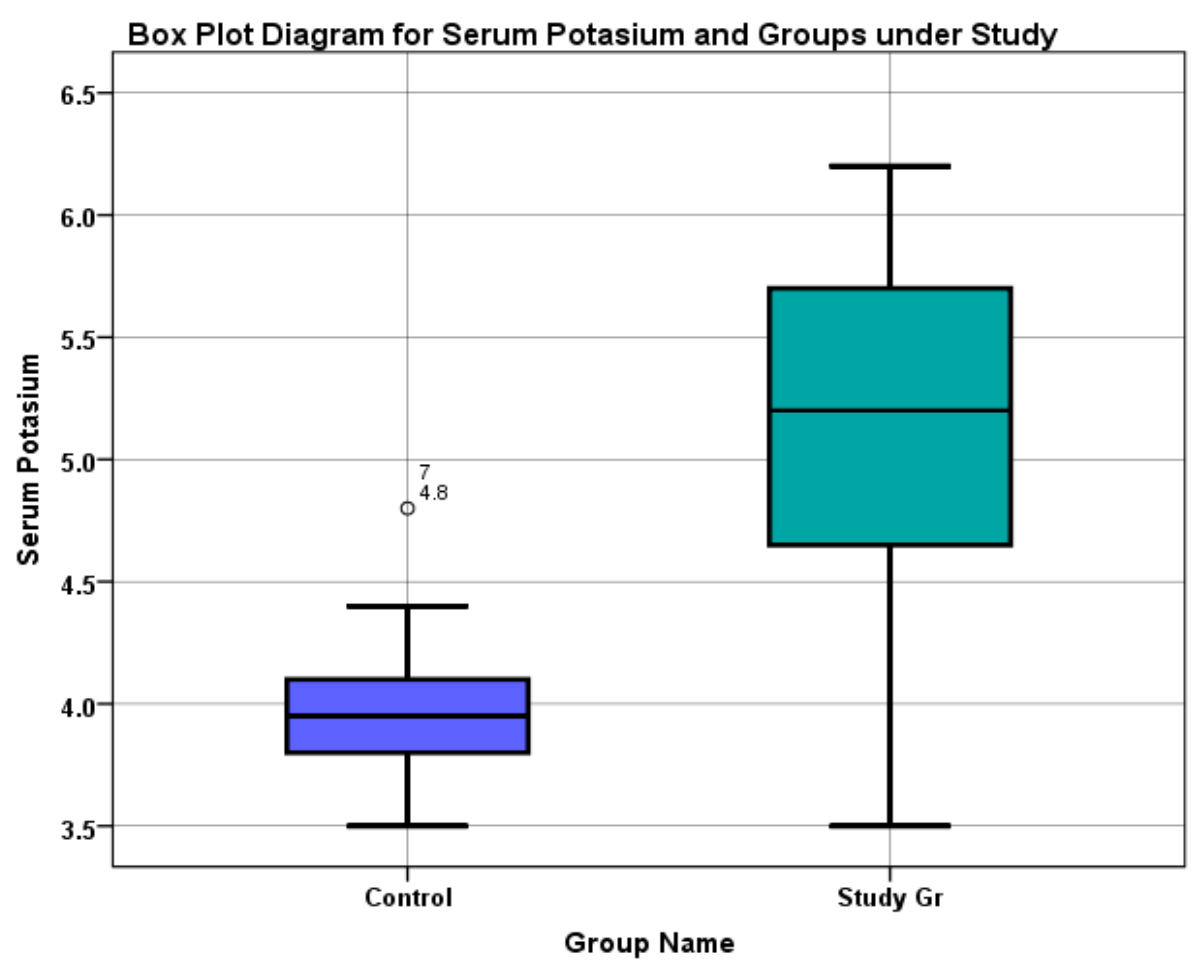

\begin{tabular}{|c|c|c|}
\hline \multicolumn{3}{|c|}{ Distribution Serum Chloride } \\
\hline Statistical Measures & Control Group & Study Group \\
\hline Mean & 102.20 & 103.65 \\
\hline Variance & 5.853 & 33.924 \\
\hline Std. Deviation & 2.419 & 5.824 \\
\hline Minimum & 96 & 90 \\
\hline Maximum & 106 & 119 \\
\hline Std. Error & .541 & 1.302 \\
\hline
\end{tabular}

Volume 4 Issue 11, November 2015 
International Journal of Science and Research (IJSR)

ISSN (Online): 2319-7064

Index Copernicus Value (2013): 6.14 | Impact Factor (2014): 5.611

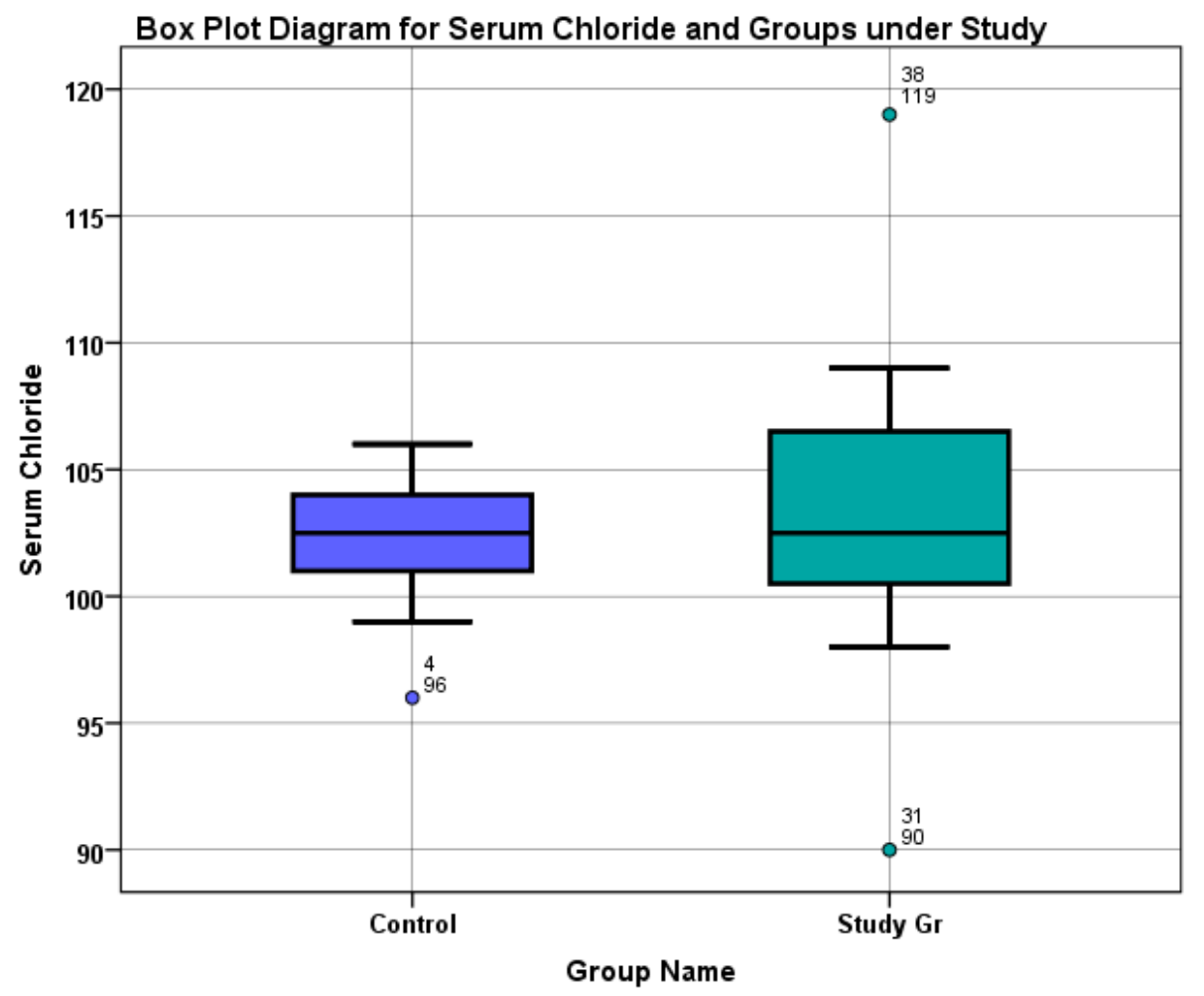

\begin{tabular}{|l|l|l|l|}
\hline t-test for Equality of Means between Study and Control \\
Group \\
\hline & t & df & Sig. (2-tailed) \\
\hline Age in years & -1.695 & 38 & .098 \\
\hline Blood Urea & -13.611 & 38 & .000 \\
\hline Serum Creatinine & -12.527 & 38 & .000 \\
\hline Serum Sodium & 1.235 & 38 & .224 \\
\hline Serum Potasium & -5.864 & 38 & .000 \\
\hline Serum Chloride & -1.028 & 38 & .310 \\
\hline
\end{tabular}

\begin{tabular}{|c|c|c|c|c|c|}
\hline \multicolumn{7}{|c|}{ ANOVA - Blood Urea } \\
\hline & Sum of Squares & df & Mean Square & F & Sig. \\
\hline Between Groups & 126337.600 & 1 & 126337.600 & 185.246 & .000 \\
\hline Within Groups & 25915.900 & 38 & 681.997 & & \\
\hline Total & 152253.500 & 39 & & & \\
\hline
\end{tabular}

\begin{tabular}{|c|c|c|c|c|c|}
\hline \multicolumn{7}{|c|}{ ANOVA - Serum Creatinine } \\
\hline & Sum of Squares & df & Mean Square & F & Sig. \\
\hline Between Groups & 698.060 & 1 & 698.060 & 156.920 & .000 \\
\hline Within Groups & 169.044 & 38 & 4.449 & & \\
\hline Total & 867.104 & 39 & & & \\
\hline
\end{tabular}

\begin{tabular}{|c|c|c|c|c|c|}
\hline \multicolumn{7}{|c|}{ ANOVA - Serum Sodium } \\
\hline & Sum of Squares & df & Mean Square & F & Sig. \\
\hline Between Groups & 48.400 & 1 & 48.400 & 1.526 & .224 \\
\hline Within Groups & 1205.500 & 38 & 31.724 & & \\
\hline Total & 1253.900 & 39 & & & \\
\hline
\end{tabular}

ANOVA - Serum Potasium

\begin{tabular}{|c|c|c|c|c|c|}
\hline \multicolumn{7}{|c|}{ ANOVA - Serum Potasium } \\
\hline & Sum of Squares & df & Mean Square & F & Sig. \\
\hline Between Groups & 12.100 & 1 & 12.100 & 34.388 & .000 \\
\hline Within Groups & 13.371 & 38 & .352 & & \\
\hline Total & 25.471 & 39 & & & \\
\hline
\end{tabular}

\begin{tabular}{|l|l|l|l|l|l|}
\hline \multicolumn{7}{|c|}{ ANOVA - Serum Chloride } \\
\hline & $\begin{array}{c}\text { Sum of } \\
\text { Squares }\end{array}$ & $d f$ & Mean Square & $F$ & Sig. \\
\hline Between Groups & 21.025 & 1 & 21.025 & 1.057 & 310 \\
\hline Within Groups & 755.750 & 38 & 19.888 & & \\
\hline Total & 776.775 & 39 & & & \\
\hline
\end{tabular}

\section{Discussion}

The present study was carried out to compare renal function in patients undergoing dialysis and normal individuals. The renal function was assessed by evaluating the concentration of blood urea, serum creatinine and electrolytes (Sodium, Potassium and Chloride).

Urea is used for managing dialysis in end stage renal failure. The level of urea in blood is used as a marker to measure the accumulation of poor renal excretory metabolites leading to the symptoms of ureamia. In the present work, the concentration of urea in blood was found to be significantly higher in study group as compared to the control group $(p<0.001)$. Serum Creatinine is used to study the filtration function of the kidney. There was tremendous increase in the creatinine levels in patients on dialysis whereas the control group individuals showed normal levels. In normal human body, the most abundant extracellular ion is the Sodium whereas the most abundant intracellular ion is Potassium. Both ions play a key role in muscle contraction.

The decrease in Sodium levels in patients on dialysis revealed the occurrence of hyponatrial condition in renal dysfunction. The levels of sodium in serum of dialysis patients were low as compared to that of individuals in the control group. The study group has higher levels of potassium in comparison to the control group $(p<0.001)$. The levels of serum chloride in bothe the groups were

\section{Volume 4 Issue 11, November 2015}




\section{International Journal of Science and Research (IJSR) \\ ISSN (Online): 2319-7064}

Index Copernicus Value (2013): 6.14 | Impact Factor (2014): 5.611

comparable. A study has demonstrated a significant reduction in mortality rate $(36 \%)$ in patients undergoing dialysis as compared to patients on conventional therapy $\left(\right.$ Mehta RL ${ }^{4}$ ). In another study it has been revealed that there was a significant decrease in hemorrhage event in patients on dialysis when compared to the conventional therapy (Metnitz $\mathrm{PG}^{5}$ ). An improvement in control of azotemia in the early course of the renal insufficiency in critically ill patients will be promising. This may result in decline in the mortality rate. The symptoms of azotemia were relieved by dialysis and patients have been maintained longer than three decades on dialysis but unfortunately average mortality rates and hospitalization are high.

\section{Acknowledgement}

We are extremely thankful to Dr. Sarib Rasool Khan, Managing Director, Shadan Institute of Medical Sciences, Teaching Hospital \& Research Centre, Hyderabad. Telangana, for his continuous encouragement and support.

\section{References}

[1] U.S. Bureau of the Census Spencer G. Current Population Reports. Series . P-25, No. 1018. Washington, D.C,: Government Printing Office; Projections of the population of the United States by age, sex and race: 1988 to 2080; pp. 1-17.

[2] Coresh J, Selvin E, Stevens LA, et al. Prevalence of chronic kidney disease in the United States JAMA. 2007; 298: 2038 - 2047.

[3] Coresh J, Astor BC, Greene T, Eknoyan G, Levey AS. Prevalence of chronic kidney disease and decreased kidney function in the adult US population: Third National Health and Nutrition Examination Survey. Am J Kidney Dis. 2003; 41: 1-12.

[4] Mehta RL, McDonald B, Gabbai FB, Pahl M, Pascual MT, Farkas A, Kaplan RM. A randomized clinical trial of continuous versus intermittent dialysis for acute renal failure. Kidney Int. $2001 \mathrm{Sep}$;00(3):1154-63.

[5] Metnitz PG, Krenn CG, Steltzer H, Lang T, Ploder J, Lenz K, Le Gall JR, Druml W. Crit Effect of acute renal failure requiring renal replacement therapy on outcome in critically ill patients. Care Med. 2002 Sep;30(9):2051-8 